\title{
Cellular Location of Prune dwarf virus in Almond Sections by In Situ Reverse Transcription-Polymerase Chain Reaction
}

\author{
Cristina Silva, Susana Tereso, Gustavo Nolasco, and M. Margarida Oliveira
}

\begin{abstract}
First, second, and fourth authors: Instituto de Biologia Experimental e Tecnológica / Instituto de Tecnologia Química e Biológica, Quinta do Marquês, 2784-505 Oeiras, Portugal; third author: Unidade de Ciências e Tecnologias Agrárias da Universidade do Algarve, Campus de Gambelas, 8000 Faro, Portugal; and fourth author: Dep. Biologia Vegetal, Fac. Ciências de Lisboa, Campo Grande 1749-016 Lisboa, Portugal.

Accepted for publication 25 October 2002.
\end{abstract}

\begin{abstract}
Silva, C., Tereso, S., Nolasco, G., and Oliveira, M. M. 2003. Cellular location of Prune dwarf virus in almond sections by in situ reverse transcription-polymerase chain reaction. Phytopathology 93:278-285.

In situ reverse transcription-polymerase chain reaction (RT-PCR) was used in young leaves (from trees and in vitro shoots) and flower buds of almond (Prunus dulcis), a stone fruit, for cellular location of Prune dwarf virus (PDV, a member of the genus Ilarvirus). Sections obtained from samples fixed in formaldehyde and embedded in paraffin were refixed in formaldehyde to increase tissue preservation in the RT-PCR steps. The coat protein gene of PDV was used as the target to produce a cDNA copy that was amplified by PCR and visualized using a direct detection

method with digoxigenin-labeled nucleotides. Protein digestion, PCR, and detection strategies were optimized for increased tissue preservation and signal intensity. PDV was found in infected samples within the vascular tissue of young leaves and flower buds as well as in the mesophyll in developing floral organs and in the generative and vegetative cells of pollen grains. PDV signals were observed in a ring surrounding the nucleus and spread in the cytoplasm. The results obtained are discussed in terms of the technique optimization and PDV distribution in tissues and transmission through pollen. The optimized protocol of in situ RT-PCR is a powerful technique to reveal low-abundant RNA species. Therefore, it is appropriate to study cell and subcellular distribution of RNA viruses in woody species.
\end{abstract}

Almond trees in Portugal, especially in Algarve, are often infected with Prune dwarf virus (PDV) and Prunus necrotic ringspot virus (PNRSV) (25). Strategies are being developed for diagnosis and introduction of resistance to PDV (30). PDV is a member of the genus Ilarvirus (family Bromoviridae) transmitted by graft, pollen, and seed $(3,17)$. The virus has a tripartite positive-sense single-stranded RNA genome. RNA 1 and RNA 2 code for proteins involved in virus genome replication and transcription. RNA 3 encodes a movement protein and the coat protein at its $3^{\prime}$-terminal end. However, the coat protein is expressed from a subgenomic RNA (RNA 4), originated by transcription from RNA 3. The RNA 4 is jointly encapsulated with the RNA 3 (3).

Meristem culture has been used as a strategy for virus elimination because it is usually assumed that at least a part of the meristematic tissues is virus-free. However, the cellular and subcellular distribution of this and many other viruses is poorly understood. Artifacts affect detection in some cases. Therefore, it is important to have an optimized technique for location of plant viruses at the tissue level. This technique should include good tissue preservation and a higher sensitivity than that achieved by immunotissue printing or other immuno- or hybridization-based strategies. The use of in situ reverse transcription-polymerase chain reaction (RTPCR), because it uses the signal amplification potential of PCR, should help elucidate virus-host interactions and viral distribution. The ability to detect and locate single copy molecules by this technique has been reported $(13,24,26)$, thus representing a significant advantage for tissues with a low virus infection rate.

Most in situ RT-PCR studies have been confined to animal tissues for the detection of RNA viruses $(6,27)$ or for studies of

Corresponding author: M. M. Oliveira; E-mail address: mmolive@itqb.unl.pt

Publication no. P-2003-0120-01R

(C) 2003 The American Phytopathological Society gene expression (22). Recently, some studies reported the adaptation of this technique to plant tissues for studies of functional genomics $(5,8,16,18,34)$ and described its adaptation for transmission electron microscopy (1).

We report, in this paper, to our knowledge for the first time, the in situ RT-PCR location of a plant virus in a woody natural host. A detailed description of the critical parameters that affect tissue preservation and the quality of the detection signals is provided. Problems such as destruction of soft tissues (in vitro samples) during the reaction steps or interference by phenols and the masking of the reaction product (samples from trees) can be avoided in optimized working conditions. The strategy described allowed us to detect PDV in leaves and flower buds, mainly distributed around nuclei of mesophyll and parenchyma cells, and around the vegetative and generative nuclei in pollen grains.

\section{MATERIALS AND METHODS}

Plant material. Leaves and flower buds were collected during February and March from field-grown almond (Prunus dulcis Mill.) trees. The samples were tested previously for PDV presence by immunological and molecular methods (enzyme-linked immunosorbent assay [ELISA] and immunocapture [IC]/RT-PCR) and used for the in situ protocol. Micropropagated almond plantlets, maintained as described by Miguel et al. (23), were also used for in situ RT-PCR. Virus-free samples were obtained from in vitro regenerated almond shoots and almond flowers that proved to be PDV-negative by IC/RT-PCR followed by Southern blotting.

ELISA and IC/RT-PCR/Southern blotting. For ELISA, Sanofi antibodies (anti-PDV immunoglobulin G) were used following the instructions of the suppliers (Sanofi Diagnostics, Pasteur, France). IC/RT-PCR was performed following the general protocol described by Raquel et al. (31). The same primers selected for in situ studies, PDV1175 and PDV1391 (described below), amplifying a 
fragment of $217 \mathrm{bp}$, were used. The reaction products were visualized by ethidium bromide staining of agarose gels or silver staining of polyacrylamide gels.

The Southern blots analyses utilized fragments separated in $1 \%$ agarose gels and transferred to a Hybond $\mathrm{N}^{+}$membrane (Amersham Biosciences, Freiburg, Germany) by alkaline treatment. The probe was prepared by PCR amplification of the same 217-bp fragment (with primers PDV1175 and PDV1391) from a template PDV-derived cDNA sequence of $722 \mathrm{bp}$, containing the coat protein gene. The 217-bp PCR-amplified fragment was extracted from an agarose gel after electrophoresis, and fluorescein-labeled following the procedures described in the Gene Images random prime labeling module kit (Amersham Pharmacia Biotech, Buckinghamshire, UK). After hybridization, the signal was detected with the Gene Images CDP-Star detection module kit (Amersham Pharmacia Biotech) as described previously.

In situ RT-PCR: Tissue preparation and sectioning. Tissues were fixed overnight in a freshly prepared $4 \%$ formaldehyde solution as described in a general protocol for in situ hybridization in plants (15). Dehydration was performed with a graded (30, 50, 70, 85,95 , and $3 \times 100 \%$ ) ethanol series (each solution containing $0.85 \% \mathrm{NaCl}$ ) over a period of 2 days. After transfer to Histo-Clear (Agar Scientific Ltd., Essex, England) for $3 \times 1 \mathrm{~h}$, tissues were embedded overnight in a 1:1 Histo-Clear/paraffin mixture (Histosec; Merck, Darmstadt, Germany). Tissues were finally embedded in $100 \%$ paraffin for 2 days at $58^{\circ} \mathrm{C}$ (paraffin solution renewed twice daily).

Paraffin blocks were prepared and stored at $4{ }^{\circ} \mathrm{C}$ until use. Sections of $5 \mu \mathrm{m}$ were obtained using a microtome (Leica RM 2155; Leica Microsistemas, Lisboa, Portugal). The sections were collected and carefully placed on drops of $30 \%$ ethanol on silanecoated in situ PCR glass slides (Applied Biosystems, Porto, Portugal) and allowed to dry for $48 \mathrm{~h}$ at $37^{\circ} \mathrm{C}$. Paraffin was removed by immersion of the slides in Histo-Clear for $5 \mathrm{~min}$ followed by $5 \mathrm{~min}$ in $100 \%$ ethanol and air dried at room temperature. The morphology of each sample was monitored at this step by staining with toluidine blue $(0.85 \%, 1 \mathrm{~min})$ and light microscopy observation prior to in situ RT-PCR. Some untreated sections were stained with 4',6-diamidino-2-phenylindole (DAPI) and observed under UV light.

The sections selected for in situ RT-PCR were then rehydrated (through a graded ethanol series) and washed in distilled water (4 min), $0.2 \mathrm{M} \mathrm{HCl}(20 \mathrm{~min}), 2 \times \mathrm{SSC}(1 \times \mathrm{SSC}$ is $0.15 \mathrm{M} \mathrm{NaCl}$ plus $0.015 \mathrm{M}$ sodium citrate) (30 min), distilled water $(5 \mathrm{~min})$, and phosphate-buffered saline (PBS; 5 min). Finally, the sections were refixed in $4 \%$ formaldehyde ( $5 \mathrm{~min}$ at room temperature) and used for the following steps.

Permeabilization. Reaction chambers were prepared by placing an adhesive box (In situ-EasiSeal; Thermo Hybaid, Ashford, Middlesex, UK) around each group of sections for the permeabilization step. Two reaction chambers were prepared for each coated slide, one with capacity for $65 \mu \mathrm{l}$ and another one with capacity for $125 \mu \mathrm{l}$. However, the volumes of reaction mixture used in these chambers in the following steps were 50 and $100 \mu \mathrm{l}$, respectively. Coverslips (Parafilm) were carefully applied to avoid air bubbles.

In order to allow RT-PCR reagents to gain access to the target sequence, the slides were treated with a pectinase (Macerozyme R10; Duchefa, Haarlem, The Netherlands) and a protease. Slides were incubated with $10 \mathrm{mg} / \mathrm{ml}$ of Macerozyme R10 for $15 \mathrm{~min}$ at $37^{\circ} \mathrm{C}$ in a humid chamber and washed for $5 \mathrm{~min}$ with sterile water. Protein digestion was achieved by incubating for $30 \mathrm{~min}$ at $37^{\circ} \mathrm{C}$ with $15 \mu \mathrm{g} / \mathrm{ml}$ of pepsin (Sigma P-6887, Sintra, Portugal). The reaction was stopped by washing the slides with a PBS solution containing $2 \mathrm{mg} / \mathrm{ml}$ of glycine (1 min) before air-drying.

DNase treatment. DNA digestion was accomplished by incubating each group of sections in $50 \mu \mathrm{l}$ (or $100 \mu \mathrm{l}$ ) of 1,000 units $/ \mathrm{ml}$ of RNase-free DNase (Roche, Carnaxide, Portugal) in $0.1 \mathrm{M}$ so- dium acetate and $5 \mathrm{mM} \mathrm{MgSO}$, $\mathrm{pH}$ 5.5. Slides were covered and incubated in a humid chamber at $37^{\circ} \mathrm{C}$ overnight and washed twice for $10 \mathrm{~min}$ in ultrapure sterile water (RNase-free).

Reverse transcription. Each group of sections was incubated with $50 \mu \mathrm{l}$ (or $100 \mu \mathrm{l}$ ) of a reaction mixture containing $20 \mathrm{mM}$ Tris- $\mathrm{HCl}(\mathrm{pH} 8.4), 50 \mathrm{mM} \mathrm{KCl}, 5 \mathrm{mM} \mathrm{MgCl} 2,0.8 \mathrm{mM}$ each dNTP, $5 \mu \mathrm{M}$ dithiothreitol, $0.8 \mu \mathrm{M}$ antisense primer PDV1391 (described below), 0.8 units/ $\mu$ of RNase Inhibitor (Applied Biosystems, Porto, Portugal), and 1 unit/ $\mu$ of Murine leukemia virus reverse transcriptase (Applied Biosystems). Slides were covered with the Parafilm coverslip and incubated at $37^{\circ} \mathrm{C}$ for $1 \mathrm{~h}$ in a humid chamber. Reverse transcription was stopped by washing twice for $10 \mathrm{~min}$ in ultrapure sterile water (RNase-free).

PCR. A PCR mix was prepared containing $20 \mathrm{mM}$ Tris- $\mathrm{HCl}$ (pH 8.4), $50 \mathrm{mM} \mathrm{KCl}, 5 \mathrm{mM} \mathrm{MgCl} 2,0.2 \mathrm{mM}$ each dNTP, $10 \mu \mathrm{M}$ digoxigenin (DIG)-11-dUTP (Roche, Carnaxide, Portugal), 0.06\% bovine serum albumin (BSA), $1 \mu \mathrm{M}$ forward primer PDV1175 (5'CCA ATT TAC TTC CAA CTT TCG A-3') and $1 \mu \mathrm{M}$ reverse primer PDV1391 (5'-TTT TAC GGG CAC ATT TGG TCC-3'), and 0.06 units/ $\mu$ l of Taq DNA polymerase (Gibco BRL, Carcavelos, Portugal). Primers were designed based on the PDV RNA 3 sequence published by Bachman et al. (3) to allow the amplification of a 217-bp cDNA fragment, starting at the intergenic region 10 nucleotides downstream of the transcription start of the RNA 4 (36) and extending to the $5^{\prime}$ terminal part of the coat protein gene. According to previous studies (33), paraffin-embedded tissues usually suffer considerable DNA and RNA degradation and short template sequences are therefore preferred for amplification.

The PCR mix (50 or $100 \mu \mathrm{l}$ ) was added to each chamber immediately after the RT reaction. Slides were then sealed using the in situ-EasiSeal coverslips and placed in an UNO-in situ thermoblock (UNO-Thermoblock; Whatman Biometra, Göttingen, Germany). The PCR program consisted of an initial denaturation step of $2 \mathrm{~min}$ at $94^{\circ} \mathrm{C}$ followed by 30 cycles of $92^{\circ} \mathrm{C}$ for $30 \mathrm{~s}, 54^{\circ} \mathrm{C}$ for $1 \mathrm{~min}$, and $72^{\circ} \mathrm{C}$ for $1 \mathrm{~min}$. A final extension step of $7 \mathrm{~min}$ at $72^{\circ} \mathrm{C}$ was applied and the samples were kept at $4^{\circ} \mathrm{C}$ until further processing. After amplification, the slides were uncovered, washed twice in PBS and 100\% ethanol, and allowed to air dry.

Before discarding the PCR mix of test samples, $1 \mu \mathrm{l}$ was collected for reamplification by conventional PCR to test for diffusion of amplified products. In this case, the PCR mix was prepared as described previously, except DIG-11-dUTP was omitted and the annealing temperature was raised to $58^{\circ} \mathrm{C}$.

Detection. The direct and the indirect detection methods were tested in preliminary studies and the direct method was chosen. Slides for the direct method were blocked in freshly prepared $2 \%$ BSA in PBS for $30 \mathrm{~min}$ after the PCR reaction. The slides were then incubated for $1 \mathrm{~h}$ in $50 \mu \mathrm{l}$ (or $100 \mu \mathrm{l}$ ) of antidigoxigenin $\left[\mathrm{Fab}^{\prime}\right]$ antibody ( 0.75 units/ $\left.\mu \mathrm{l}\right)$ (Roche) conjugated with alkaline phosphatase diluted $1: 250$ in $100 \mathrm{mM}$ Tris- $\mathrm{HCl}$ and $150 \mathrm{mM}$ $\mathrm{NaCl}, \mathrm{pH}$ 7.5. Slides were washed twice for $5 \mathrm{~min}$ in $0.1 \mathrm{M}$ Tris$\mathrm{HCl}$ and $0.15 \mathrm{M} \mathrm{HCl}, \mathrm{pH} 9.5$, and detection was carried out for 10 to $30 \mathrm{~min}$ using nitroblue tetrazolium/5-bromo-4-chloro-3-indolylphosphate toluidinium (Roche). Slides were then rinsed in water for $5 \mathrm{~min}$ and sections were kept humid in darkness to prevent nonenzymatic precipitation of the hydrolyzed product. Sections were observed with a light microscope (Nikon Eclipse TE 300; Nikon, Surrey, UK) and images were registered on Fuji 200 ASA color films (Fuji Photo Film, Tokyo).

Controls. Several controls were performed (Table 1) to monitor the reaction conditions in terms of accessibility of the reagents and specificity of the signal.

\section{RESULTS}

ELISA and IC/RT-PCR for PDV detection in almond tissues. ELISA performed on almond young leaves and flower buds collected from the field (region of Monsanto, Lisboa) revealed a 
strong presence of PDV, with absorbance values of $1.0<\mathrm{A} 405>2.5$, validated by calculation of the detection threshold.

IC/RT-PCR performed on the same samples produced a strong signal (Fig. 1a). However, neither ELISA nor IC/RT-PCR yielded positive results for in vitro-propagated material. PDV-positive samples, however, could be detected after Southern blotting and hybridization with the cDNA fragment of 217 bp of PDV coat protein gene (Fig. 1b).

The virus-free in vitro samples (negative control 0) were negative by all tested methods (Fig. 1). Pieces of virus-free almond flowers, selected from PDV-negative trees (maintained at the Agricultural Research Services of Mirandela, Trás-os-Montes) and after molecular confirmation of PDV absence, were also used as negative controls for in situ RT-PCR.

Optimization of the in situ RT-PCR protocol. Initially, sections of 8 to $10 \mu \mathrm{m}$ were obtained for in situ RT-PCR because, according to $\mathrm{Gu}$ (13), a thickness over $7 \mu \mathrm{m}$ may be more appropriate when there is a low availability of the target sequence. However, these sections easily detached from the coated slides during the RT-PCR procedure. This problem was avoided by reducing the thickness to $5 \mu \mathrm{m}$.

Rehydration and refixation after tissue sectioning were essential to preserve the tissue integrity through the PCR steps. This was verified by comparison with sections in which these steps were omitted, resulting in an increase in tissue destruction and difficulty in signal detection.

Proteinase $\mathrm{K}$ was used for protein digestion at concentrations ranging from 6 to $14 \mu \mathrm{g} / \mathrm{ml}$ over 30 or $60 \mathrm{~min}$ in the initial assays. These treatments, however, resulted in strong tissue destruction and almost complete absence of reaction signals, which reveals over-digestion (13). Pepsin, as an alternative, was assayed at 6, 8, 10,15 , and $20 \mu \mathrm{g} / \mathrm{ml}$ for $30 \mathrm{~min}$. Optimal permeabilization was achieved with $15 \mu \mathrm{g} / \mathrm{ml}$ of pepsin, shown by the good tissue preservation and strong nuclear signal obtained with the reagent control (Table 1; Fig. 2a).

The indirect detection method was used in the initial experiments in which a specific cDNA DIG-labeled probe was hybridized to the amplified product. However, this detection strategy strongly increased tissue destruction and caused loss of reaction signals. This was presumably due to leakage because it was not possible to obtain good signals even in the reagent controls. Thus, this strategy was replaced by the direct labeling of the PCRamplified products with good results as shown in Figures 2 and 3.

The efficiency of the optimized protocol was supported by the absence of signal in the negative controls (Figs. 2d and 3e, absence of PDV; Fig. 2b, absence of RT; Fig. 2c, absence of primers; and Fig. 3a and $\mathrm{f}$, the absence of Taq polymerase) Table 1 provides a list of controls.

Study of PDV distribution. PDV could be detected in infected leaves and flower buds by in situ RT-PCR. This result was in agreement with the immuno- and molecular detection methods previously applied to the same material.

In our experiments, PDV was observed at the nuclear region of infected cells and in the cytoplasm of the dense cells of the vas- cular tissue both in leaves and flower buds (Figs. $2 \mathrm{f}$ and $\mathrm{g}$ and $3 \mathrm{~b}$ to d). The nuclear location of the stronger reaction signals observed after in situ RT-PCR was confirmed by DAPI staining of nuclei in untreated sections (Fig. $2 \mathrm{~h}$ to j). The nuclei occupied a central position in cytoplasmic dense cells (Fig. 2j). They appeared compressed against the cell wall in vacuolated cells (Fig. 2h) and appeared elongated in longitudinal sections of vascular tissue (Fig. 2i).

In flower buds, the positive reaction was observed at the vascular system and the parenchyma cells of the hypanthium and at the ovary wall (Fig. 3b and c). A strong reaction was also visible in the young developing ovules (Fig. $3 \mathrm{~b}$ and d). The reaction product in these cells was observed at the nuclear level, whereas a weaker reaction was visible in the cytoplasm. In the higher magnifications, the signals at the nuclear level appeared with a ring shape (Fig. 3d and insert, arrows). The reaction product, in most anthers, was observed also inside immature pollen grains. Here again, the product was mainly observed surrounding the nucleus both in the vegetative cell and in the generative one (Fig. $3 \mathrm{~g}$ and $\mathrm{h}$ ). It was found and confirmed by observation of serial sections that not all anthers in a flower bud contain infected pollen grains, which may reflect heterogeneous virus distribution during early stages of stamen emergence. The omission of Taq polymerase from the reaction mixture in sections of anthers that were positive for PDV by IC/RT-PCR resulted in pollen grains that did not stain purple. Also, the nuclear region was clearly unstained (Fig. 3f). An identical clean aspect was observed on pollen grains of virus-free samples (Fig. 3e).

The accumulations of phenolic compounds (tannins) in fieldcollected samples did not interfere with the reactions and could be distinguished by their yellowish or light brown color (Figs. $2 \mathrm{~g}$ and $3 a$ and $b$ ).

\section{DISCUSSION}

Technique optimization. We have optimized in situ RT-PCR for detection of viral RNA in almond tissues by testing a number of parameters for improved preservation of both target RNA and cellular structure.

Aldehyde fixation was chosen due to its efficiency in stabilizing cross-links and creating a physical barrier for molecules that otherwise might diffuse across the cellular structures (16). The protease treatment required to partially break down the meshwork created by the fixation is essential to allow reagent penetration, but a compromise between appropriate fixation and efficient permeabilization must be achieved. The proteases most commonly used in in situ RT-PCR are proteinase K, pepsin, and trypsin (26). The appropriate protease and its concentration have to be tested for each kind of target tissue and fixation/embedding procedure. Under-digestion results in poor permeability and extensive crosslinking between proteins and nucleic acids, which interferes with the PCR and yields false negative results. Proteinase K was too aggressive under our experimental conditions. Even the lower concentrations tested resulted in significant tissue damage, loss of

TABLE 1. Series of controls used to monitor the reaction conditions ${ }^{\mathrm{a}}$

\begin{tabular}{|c|c|c|c|c|c|}
\hline Control & Negative control 0 & Reagent control & Negative control 1 & Negative control 2 & Negative control 3 \\
\hline Prune dwarf virus presence & - & + & + & + & + \\
\hline DNase treatment & + & - & + & + & + \\
\hline Reverse transcriptase treatment & + & - & - & + & + \\
\hline Presence of primers & + & + & + & - & + \\
\hline Presence of Taq polymerase & + & + & + & + & - \\
\hline Expected results & No signal & Strong signal at the nucleus & No signal & No signal & No signal \\
\hline
\end{tabular}

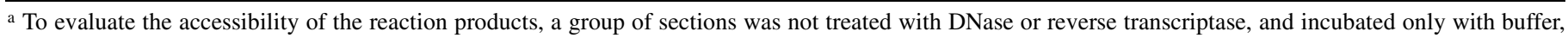
and further processed as test slides (reagent control). In this control, if there is a good access of the reagents, development of signal at the nuclear level should result from the amplification of DNA fragments that act as unspecific primers. The negative controls (1 to 3 ) provide information regarding the reliability and specificity of the signal detected. + indicates reaction step performed; - indicates reaction step omitted. 
sections from the coated slides, and absence of reaction signal. Improved tissue preservation was achieved with pepsin although some tissue destruction was observed following PCR. According to Bates et al. (4), this damage is inevitable due to the repeated heating steps. The absence of DNase treatment resulted in the observation of a strong nuclear signal in the reagent control. This was as expected. This result indicates that enough, but not excessive, digestion occurred thereby allowing penetration of the reaction mixture and the in situ retention of the amplified products.

Other important parameters included (i) decreasing the thickness of the sections $(5 \mu \mathrm{m})$; (ii) refixing the sectioned material; and (iii) PCR-amplifying with 30 cycles instead of 40 (data not shown). Gu (13) recommended 25 to 40 cycles for in situ PCR. We selected 30 cycles because it allowed development of signal and reduced the exposure of the sections to the damaging high temperatures.

The primers selected for PCR amplification produced a small sequence of $217 \mathrm{bp}$. Although larger sequences can be more easily retained in the meshwork, the amplification of smaller sequences (200 to $300 \mathrm{bp}$ ) is usually recommended according to Johansen (16). Larger sequences may not be detected due to degradation of RNA template during tissue preparation procedures (22).

Our initial choice of the indirect method for detection of the amplification products was based on prior reports on the increased reliability of this strategy compared with the direct detection method $(19,21,32)$. The incorporation of labeled nucleotides (DIG-11-dUTP or fluorescein-dUTP) during PCR, used in the direct method, may give rise to nonspecific results if mispriming, primer oligomerization, or DNA repair mechanisms are operating inside the cell $(19,21,32)$. However, appropriate reaction conditions and controls may eliminate these possibilities. The direct method proved to be more efficient than the indirect one for PDV detection in almond tissues and yielded superior tissue preservation and retention of the amplified fragments at the subcellular level. The absence of signal after PCR reamplification of the reaction mixture collected from the chambers does not prove that product diffusion between adjacent cells does not occur. This, however, does not seem to be a major problem due to the consistent labeling of specific tissues (Fig. 3b) and reproducible signal in serial sections.

The results from reagent and negative controls were performed in parallel with the test samples. This allowed us to monitor the reaction conditions and exclude possible nonspecific effects. False positive results associated with in situ RT-PCR are mainly due to nonspecific incorporation of labeled nucleotides, which occurs by DNA polymerase exonuclease activity or when DNA or cDNA fragments act as unspecific primers. Both situations can be detected if a signal is visualized in a negative control obtained by omission of primers. A faint staining with no specific location was often visualized in the different negative controls, although it was less common in the absence of Taq polymerase. According to Long and Komminoth (20), this background staining will never disappear even in DNase-digested samples. Consequently, a positive result in test samples must be much stronger and localized, as was the case in our experiments. Aparicio et al. (2) used in situ hybridization with a nonradioactive riboprobe corresponding to the full-length cDNA of PNRSV RNA 4 for in situ location of PNRSV. They used gold-labeled sheep antidigoxigenin followed by silver enhancement treatment to detect the signal. Their observations were made with a combination of epipolarization and phase contrast microscopy. However, in situ RT-PCR offers the advantage of amplifying low copy RNA molecules to make them detectable. This strategy allowed us to detect virus presence in tissues of in vitro propagated plant material (Fig. 2e and f), whereas the use of IC/RT-PCR could only detect signals if combined with Southern blotting (Fig. 1a and b, ivP). This result clearly demonstrates the high sensitivity of in situ RT-PCR for detection of RNA viruses in sections of plant tissues.
PDV location. No heterologous biological vector has been identified in plant-to-plant transmission of PDV or other ilarviruses. Suggestions have been made that thrips can facilitate the transmission of PDV and PNRSV from cherry pollen to cucumber (12). Pollen, seed, vegetative propagation, or cultural practices have been considered as the key factors responsible for spread of ilarviruses $(7,10,14,29,35)$.

Previous studies reported ilarviruses at the surface of Prunoideae (almond and cherry) pollen grains or located inside near the pollen grain pores. Cole et al. (7) noticed that in almond and cherry trees most PNRSV particles could be removed from pollen by washing, but they considered there was a great variability in terms of either location or strength of the antigen attachment. Later, Kelley and Cameron (17), using an improved protocol for pollen disruption (grinding), found that PDV is carried internally in sweet cherry pollen. They observed PDV particles concentrated in the areas beneath the pores by transmission electron microscopy. Kelley and Cameron (17) considered such results as artifacts due to clustering of particles near the pores through which the fixative (permanganate) penetrated. This resulted in the loss of internal virus particles due to insufficient fixation and further processing. Also, virus particles were never observed in PNRSV-infected pollen grains in spite of the strong positive ELISA of washed and grounded pollen grains. They explained this as a consequence of the permanganate fixation. Although Kelley and Cameron (17) could prove the internal location of the virus, they could not study its distribution. The results we obtained for PDV location in almond pollen confirm its presence in pollen and provide evidence of its location within this tissue. In another stone fruit, Prunus persica, Aparicio et al. (2) detected, by in situ hybridization, PNRSV located in the cytoplasm of the vegetative cell of pollen grains but not in the generative cell. They suggested that the sperm cells, formed by mitosis of the generative cell, are not involved in virus transmission to seed. This does not seem to be the case for PDV transmission in almond because, in numerous pollen grains, we found strong signals not only in the vegetative cell but also in the cytoplasm and around the nucleus of the generative
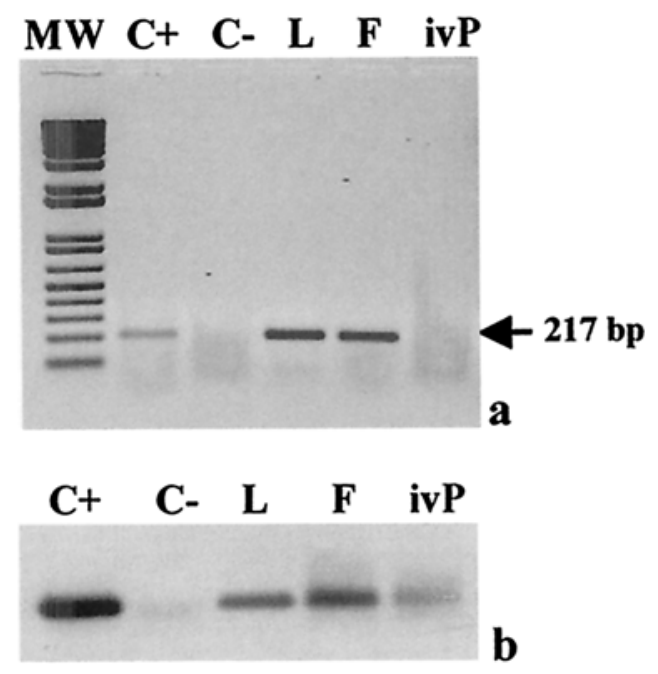

Fig. 1. Immunocapture-reverse transcription-polymerase chain reaction (IC/RT-PCR) for Prune dwarf virus (PDV) detection in almond tissues. AntiPDV immunoglobulin $\mathrm{G}$ and PDV-infected tissue, as a positive control $(\mathrm{C}+)$, were used in these experiments. A sequence of $217 \mathrm{bp}$ was amplified from cpPDV RNA 4 using the primer combinations described in the text. $\mathrm{C}$-, negative control corresponding to in vitro propagated virus-free almond plantlets; $\mathrm{L}$ and F, material collected from PDV-infected trees (L, leaves; F, flower buds); ivP, PDV-infected in vitro plantlets; MW, 1-kb DNA Plus ladder. a, Ethidium bromide-stained agarose gel with the IC/RT-PCR products. b, Southern blotting of the same samples shown in a and hybridized to a PCRlabeled digoxigenin probe. In PDV-infected in vitro material, virus presence is recognized only after Southern blotting. 

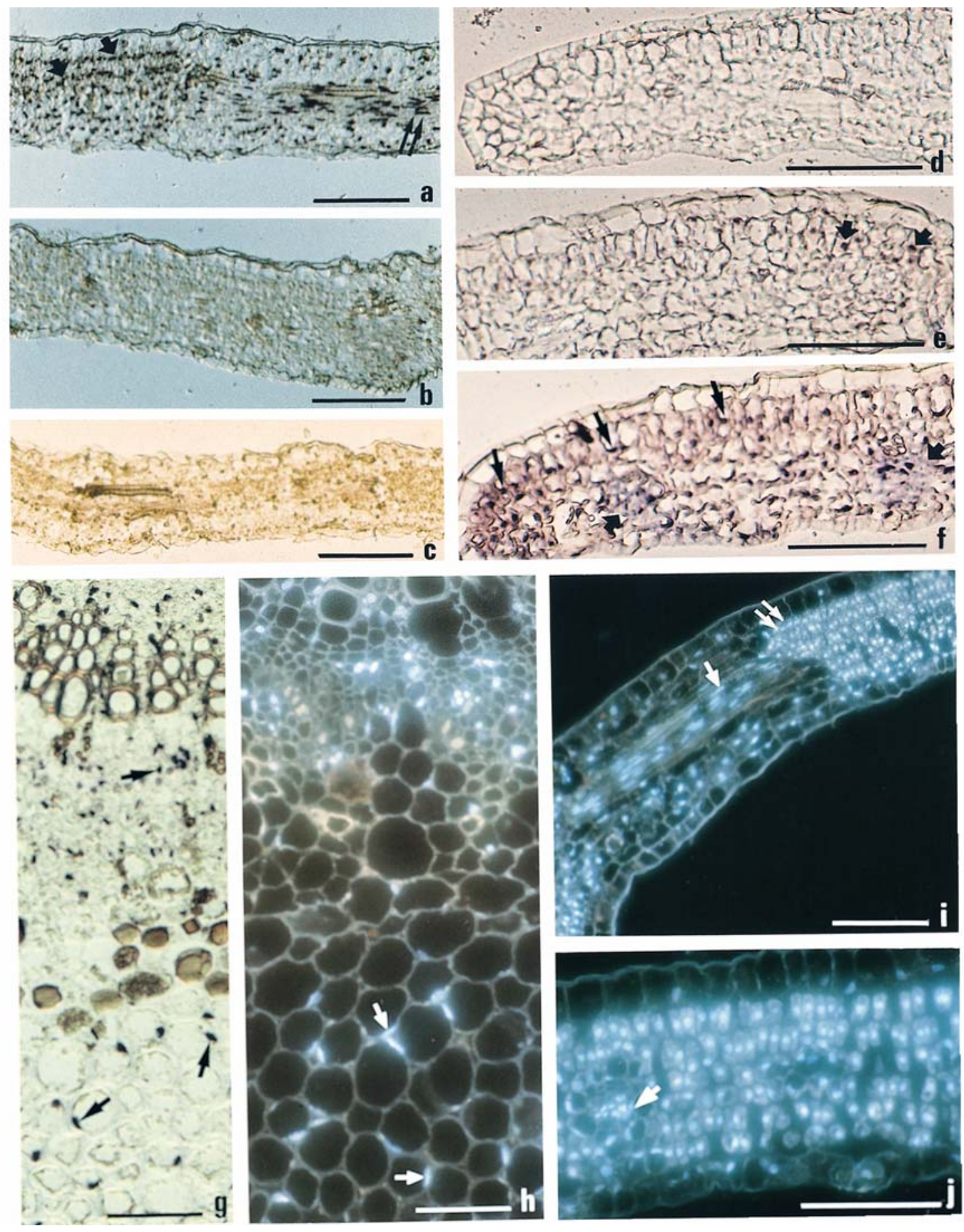

Fig. 2. Images of in situ reverse transcription-polymerase chain reaction (RT-PCR) tests and controls performed on almond leaves for cellular location of Prune dwarf virus (PDV). PDV-infected samples were obtained from young leaves of field-grown trees (a, $\mathbf{b}, \mathbf{c}, \mathbf{a n d} \mathbf{g})$ and from leaves of micropropagated shoots (e and f). Image $\mathbf{d}$ was taken from a PDV-free in vitro shoot (negative control 0). Images $\mathbf{h}$ to $\mathbf{j}$ were taken from 4',6-diamidino-2-phenylindole (DAPI)-stained leaf sections obtained from field material, as morphology controls. a to c, Controls of the reaction conditions: a, reagent control (absence of DNase and reverse transcriptase treatment). The clear staining of the nuclei demonstrates the efficient access of the reaction mix. In the two cell layers of the palisade parenchyma, nuclei appear aligned (arrows), whereas in the spongy parenchyma, they appear less aligned. In the oblique section of a lateral vein, elongated nuclei (double arrow) are visible in the vascular cells. b, Negative control 1. In the absence of reverse transcription, PDV-infected leaves (immunocapture/RT-PCR analyses shown in Fig. 1a, L) reveal no positive signal. c, Negative control 2. On the same PDV-infected samples, no signal is visible when primers were omitted from the PCR reaction. d, Section through a leaf of a micropropagated PDV-negative plantlet (negative control 0) (Fig.1b, C-), showing absence of virus signal. All the tissues, including the vascular tissue, appear to be free of signal. e and f, Test reactions performed on leaves of PDV-infected micropropagated plantlets showing different reaction intensities. In image e, a weak positive signal is observed by the staining of few nuclei (arrows), whereas in image f, strong staining is observed at the nuclear level (thin arrows) and a faint purple staining can also be seen in the cytoplasm, particularly near vascular tissue (large arrows). $\mathbf{g}$, Section through the main vein of a leaf showing positive signal at the nuclear level for various cell types such as the collenchyma and the vascular cells (arrows). The brown inclusions are typical phenolic accumulations of almond tissues. h, Section similar to image $\mathbf{g}$, showing the tissue morphology after DAPI staining for nuclei (arrows). Notice, in collenchyma cells, the bright blue nuclei appearing compressed against the wall (arrows) and, in the small vascular cells, occupying most of the cellular space. i, DAPI staining of a field tree leaf blade showing nuclei distribution. Notice the nuclei in elongated forms in longitudinal sections of lateral veins (arrow), the parallel distribution of round-shaped nuclei in palisade parenchyma (double arrow) and more disperse distribution in spongy parenchyma. $\mathbf{j}$, Detail of part of the leaf of image $\mathbf{i}$. Notice the nuclei in a cross section of a lateral vein (arrow). a to $\mathbf{c}$ and $\mathbf{i}, \mathrm{Bars}=100 \mu \mathrm{m} ; \mathbf{d}$ to $\mathbf{h}$ and j, bars $=50 \mu \mathrm{m}$. 

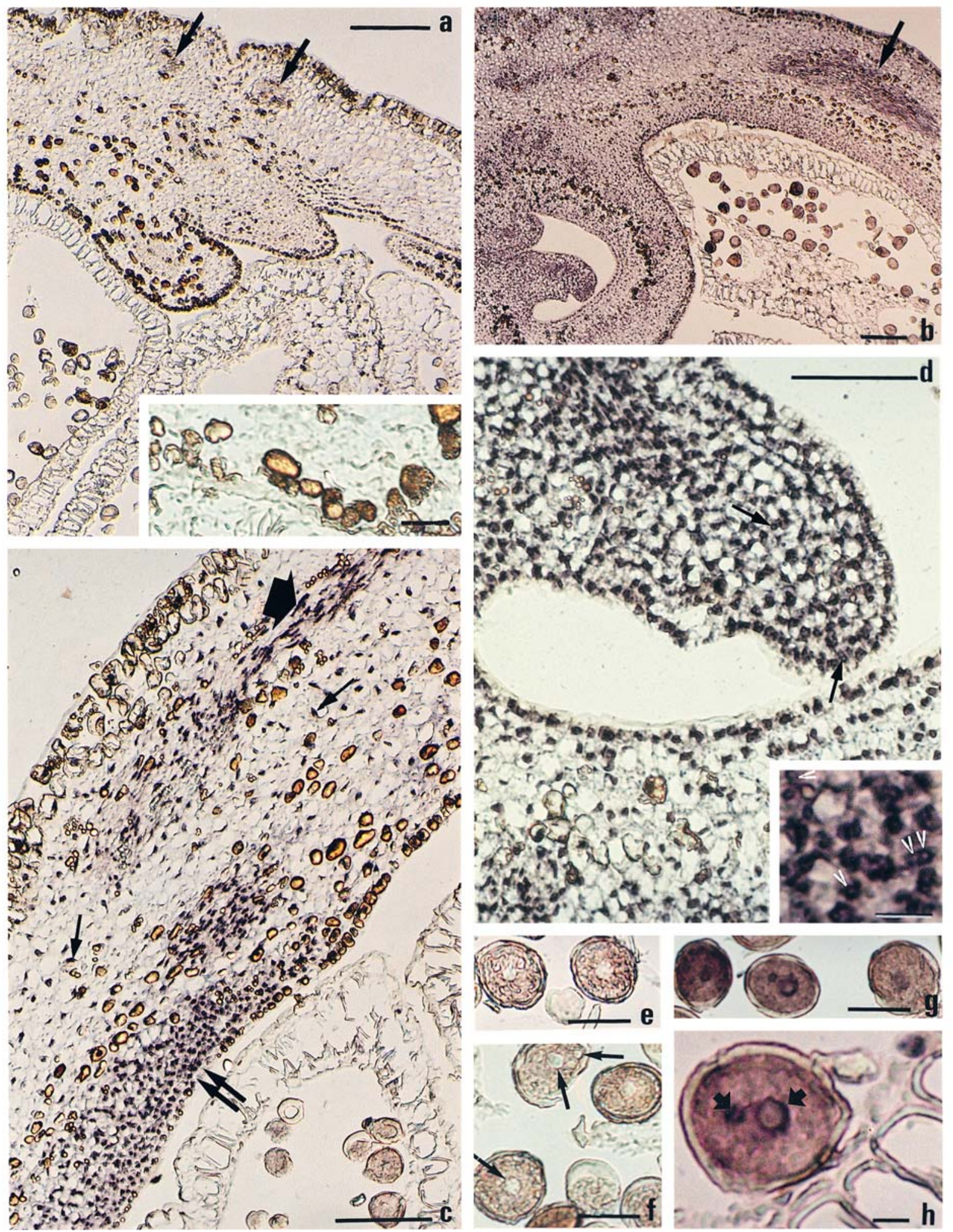

Fig. 3. Images of in situ reverse transcription-polymerase chain reaction (RT-PCR) tests and controls performed on almond flower buds for cellular location of Prune dwarf virus (PDV). a, Negative control 3 (omission of Taq polymerase in the PCR reaction). Part of a flower bud is shown, including anthers and hypanthium with sectioned vascular bundles (arrows), and no reaction is visible. The large brown-yellow inclusions, visible in numerous cells correspond to tannin accumulations and are more clearly shown in the insert. b. Image of part of a flower bud showing strong PDV signals. The signals are visible on a young ovary with two developing ovules at the stage of integument emergence, and at the basis of the hypanthium, in particular at the vascular level (arrow). c, Detail of part of the hypanthium showing the location of PDV signals more clearly visible at the nuclear level. Positive signals are visible on elongated nuclei at the vascular cells (large arrow), parenchyma cells (thin arrows), and meristematic cells at the adaxial side of the organ (double arrows). In the less-vacuolated cells some purple staining is also visible at the cytoplasm. d, Detail of the ovary wall and young ovule showing stained nuclei. In some nuclei, the PDV signals are visible with a ring-shape (arrows), but this aspect is clearer in the insert (arrow heads). e, Section through pollen grains of a PDV-free flower bud, showing no reaction signals from the nucleus or cytoplasm. f, Detail of pollen grains of the flower bud shown in a (negative control 3). No reaction signals are visible and the generative and vegetative nuclei (arrows) are colorless. $\mathbf{g}$ and $\mathbf{h}$, Pollen grains showing virus signal, recognized by an intense purple staining. A stronger reaction is observed around both the generative nucleus (larger nucleus) and the vegetative one (h, arrows), but signal is also visible in the cytoplasm of both cells, although to a variable degree in individual pollen grains (g). a and b, Bars $=100 \mu \mathrm{m}$; $\mathbf{c}$ and $\mathbf{d}$, bars $=50 \mu \mathrm{m}$; $\mathbf{e}$ to $\mathbf{g}$, bars $=20 \mu \mathrm{m}$; inserts in $\mathbf{a}$ and d, bars $=10 \mu \mathrm{m} ;$ and $\mathbf{h}$, bar $=5 \mu \mathrm{m}$. 
cell. This virus location may constitute a strategy to ensure the successful transfer of virus to the female gametophyte (egg cell and central cell) during the double fertilization process. Although infection has been reported to be one of the causes of reduced pollen viability, including its abortion, it does not seem to compromise horizontal virus transmission (28). How the virus spreads in the fertilized plant however is not yet clear, although this transmission route is epidemiologically important (11).

Virus distribution around the nuclei, observed clearly in pollen grains and to a lesser extent in other cells, was reported previously for another ilarvirus. Edwardson and Purcifull (9) verified by transmission electron microscopy that Tobacco streak virus presents a similar distribution in shoot tip cells of Datura stramonium. They showed that high amounts of aggregated virus particles were arranged in strands and formed a ring around the nuclear envelope. From our results, it is likely that an identical distribution occurs for PDV in almond cells.

The PDV transport mechanism in cell-to-cell or long-distance transmission is not clear. The only vegetative organs used in our study of virus distribution were young leaves. Here, the signals were mainly detected in vascular tissues and parenchyma cells. The consistent detection of PDV in the vascular tissue suggests that this is at least one of the systems used for virus transport throughout the plant. However, virus transmission through cell division may also be a possibility.

In conclusion, the results of this investigation indicate that in situ RT-PCR may be a useful tool to study the distribution of RNA viruses in woody natural hosts and can contribute to the understanding of viral transmission mechanisms. Moreover, our results support the idea of sexual reproduction and ovule fertilization as a way of PDV spread in an almond orchard. This situation is of high significance in a species in which most cultivars are self-incompatible and pollen transfer between different cultivars is required for seed set.

\section{ACKNOWLEDGMENTS}

This work was supported by PRAXIS XXI 3/3.2/HORT/2143/95. We thank $\mathrm{H}$. Raquel for providing the in vitro plant material, B. Johanson for helpful suggestions regarding technique optimization, M. M. O. Krause for critically revising the manuscript and improving the English, and J. Becton for the final revision. We also acknowledge the careful and detailed suggestions of R. Nelson during the revision process of our paper.

\section{LITERATURE CITED}

1. Alché, J. D., Castro, A. J., and Rodríguez-Garcia, M. I. 2002. Localization of transcripts corresponding to the major allergen from olive pollen (Ole e I) by electron microscopic non-radioactive in situ RT-PCR. Micron 33:33-37.

2. Aparicio, F., Sánchez-Pina, M. A., Sánchez-Navarro, J. A., and Pallás, V. 1999. Location of Prunus necrotic ringspot Ilarvirus within pollen grains of infected nectarine trees: Evidence from RT-PCR, dot-blot and in situ hybridization. Eur. J. Plant Pathol. 105:623-627.

3. Bachman, E. J., Scott, S. W., Xin, G., and Vance, V. B. 1994. The complete nucleotide sequence of Prune Dwarf Ilarvirus RNA 3: Implications for coat protein activation of genome replication in Ilarviruses. Virology 201:127-131.

4. Bates, P. J., Sanderson, G., Holgare, S. T., and Johnston, S. L. 1997. A comparison of RT-PCR, in-situ hybridisation and in-situ RT-PCR for detection of rhinovirus infection in paraffin sections. J. Virol. Methods 67:153-160.

5. Bombelli, L., Doneda, L., Tonelli, G., and Dolfini, S. 1998. In situ reverse transcription-PCR in plant tissues. Elsevier Trends Journals. (Technical Tips Online) TTO 1:34:P01242.

6. Chiu, K.-P., Cohen, S., Morris, D., and Jordan, G. 1992. Intracellular amplification of proviral DNA in tissue sections using polymerase chain reaction. J. Histochem. Cytochem. 40:333-341.

7. Cole, A., Mink, G. I., and Regev, S. 1982. Location of Prunus necrotic ringspot virus on pollen grains from infected almond and cherry trees. Phytopathology 72:1542-1545.
8. Deeken, R., and Kaldenhoff, R. 1997. Light-repressible receptor protein kinase: A novel photo-regulated gene from Arabidopsis thaliana. Planta 202:479-486.

9. Edwardson, J. R., and Purcifull, D. E. 1974. Relationship of Datura quercina and Tobacco streak viruses. Phytopathology 64:13221324.

10. Fulton, R. W. 1970. Prunus necrotic ringspot virus. No. 5 in: Descriptions of Plant Viruses. Commonw. Mycol. Inst./Assoc. Appl. Biol., Kew, England.

11. Garret, R. G., Cooper, J. A., and Smith, P. R. 1985. Virus epidemiology and control. Pages 269-279 in: The Plant Viruses. R. I. Francki, ed. Plenum Press, New York.

12. Greber, R. S., Teakle, D. S., and Mink, G. I. 1992. Thrips-facilitated transmission of prune dwarf and prunus necrotic ringspot viruses from cherry pollen to cucumber. Plant Dis. 76:1039-1041.

13. Gu, J. 1995. In situ PCR an overview. Pages 1-21 in: In Situ PCR and Related Technology. J. Gu, ed. Eaton Publishing, Boston.

14. Howell, W. E., and Mink, G. I. 1988. Natural spread of cherry rugose mosaic disease and two prunus necrotic ringspot virus biotypes in a central Washington sweet cherry orchard. Plant Dis. 72:636-640.

15. Jackson, D. 1991. In situ hybridization in plants. Pages 163-174 in: Molecular Plant Pathology: A Practical Approach. D. J. Burries, G. J. Gurr, and M. Macthereson, eds. Oxford University Press, Oxford, England.

16. Johansen, B. 1997. In situ PCR on plant material with sub-cellular resolution. Ann. Bot. 80:697-670.

17. Kelley, R. D., and Cameron, H. R. 1986 Location of prune dwarf and prunus necrotic ringspot viruses associated with sweet cherry pollen and seed. Phytopathology 76:317-322.

18. Koltai, H., and Bird, D. M. 2000. High throughput cellular localization of specific plant mRNAs by liquid-phase in situ reverse transcriptionpolymerase chain reaction of tissue sections. Plant Physiol. 123:12031212.

19. Komminoth, P., Adams, V., Long, A. A., Roth, J., Saremaslani, P., Flury, R., Schmid, M., and Heitz, P. U. 1994. Evaluation of methods for hepatitis $\mathrm{C}$ virus detection in archival liver biopsies. Comparison of histology, immunohistochemistry, in-situ hybridization, reverse transcriptase polymerase chain reaction (RT-PCR) and in-situ RT-PCR. Pathol. Res. Pract. 190:1017-1025.

20. Long, A. A., and Komminoth, P. 1995. In situ PCR: General methodology and recent advances. Pages 23-34 in: In situ PCR and Related Technology. J. Gu, ed. Eaton Publishing, Boston.

21. Long, A. A., Komminoth, P., Lee, E., and Wolf, H. 1993. Comparison of indirect and direct in situ polymerase chain reaction in cell preparations and tissue sections. Detection of viral DNA, gene rearrangements and chromosomal translocations. Histochemistry 99: 151-162.

22. Martinez, A., Millen, M. J., Quinn, K., Unsworth, E. J., Ebina, M., and Cuttitta, F. 1995. Non radioactive localisation of nuclei acids by direct in situ PCR and in situ RT-PCR in paraffin-embedded sections. J. Histochem. Cytochem. 43:739-747.

23. Miguel, C., Druart, P., and Oliveira, M. M. 1996. Shoot regeneration from adventitious buds induced on juvenile and adult almond (Prunus dulcis Mill.) explants. In Vitro Cell. Dev. Biol. Plant 32:148153.

24. Muro-Cacho, C. A. 1997. In situ PCR. Overview of procedures and applications. Front. Biosci. 2:C15-29.

25. Nolasco, G., Neves, M. A., and Faria, E. A. 1991. Distribuição no Algarve de vírus do grupo Ilarvirus em amendoeira e suas consequências na produção-1 a aproximação. Rev. Cienc. Agrar. 15:33-37.

26. Nuovo, G. J. 1996. The foundation of successful RT in situ PCR. Front. Biosci. 1:C4-15.

27. Nuovo, G. J., Lindonnici, P., MacConnell, P., and Lane, B. 1993. Intracellular localisation of polymerase chain reaction (PCR)-amplified hepatitis-C. Am. J. Surg. Pathol. 17:683-690.

28. Nyeki, J., and Vertesy, J. 1974. Effects of different ringspot viruses on the physiological and morphological properties of cv. Montmorency sweet cherry pollen II. Acta Phytopathol. Acad. Sci. Hung. 9:23-29.

29. Pethybridge, S. J., Wilson, C. R., and Leggett, G. W. 1998. Virus incidence and spread in Australian triploid hops (Humulus lupulus L.). Acta Hortic. 471:105-110.

30. Raquel, M. H., Miguel, C., Nolasco, G., and Oliveira, M. M. 2000. Construction of a transformation vector aiming at introduction of PDV resistance in almond. Acta Hortic. 521:73-81.

31. Raquel, M. H., Tereso, S., Oliveira, M. M., and Nolasco, G. 1999. Establishing a protocol for IC-RT-PCR detection of Prune dwarf virus in almond. Petria 9:153-156.

32. Sälström, J., Zehbe, I., Alemi, M., and Wilander, E. 1993. Pitfalls of in 
situ polymerase chain reaction (PCR) using direct incorporation of labeled nucleotides. Anticancer Res. 13:1153.

33. Stanta, G., and Scheider, C. 1991. RNA extracted from paraffin-embedded human tissues is amenable to analysis by PCR amplification. Biotechniques 11:3.

34. Urbanczyk-Wochniak, E., Filipecki, M., and Przybecki, Z. 2002. A useful protocol for in situ RT-PCR on plant tissues. Cell. Mol. Biol. Lett.
7:7-18.

35. Uyemoto, J. K., Asai, W. K., and Luhn, C. F. 1992. Ilarviruses: Evidence for rapid spread and effects on vegetative growth and fruit yields of peach trees. Plant Dis. 76:71-74.

36. Vasková, D., Petrzik, K., and Spak, J. 2000. Molecular variability of the capsid protein of the prune dwarf virus. Eur. J. Plant Pathol. 106: 573-580. 